\title{
Catalytic Effects and Characteristics of Ni-based Catalysts Supported on $\mathrm{TiO}_{2}-\mathrm{SiO}_{2}$ Xerogel
}

\author{
Jong-Woo Jeong, Jong-Hui Park, Sung-Woo Choi, ${ }^{\dagger}$ Kyung-Hee Lee, ${ }^{,}$and Chang-Seop Lee ${ }^{\star}$ \\ Department of Chemistry, Keimyung University, Daeg7 704-701, Korea. "E-mail: sntrkm(akmu.ac.kr \\ "Department of Energy and Envirommental Science, Keimyning University, Daegu 704-701, Korea \\ ${ }^{+}$Department of Gas Indhistry, Kundong University, Andong 760-830, Korea \\ Received May 19, 2007
}

\begin{abstract}
The catalytic activities of nickel-based catalysts were estimated for oxidizing acetaldehyde of VOCs exhausted from industrial facilities. The catalysts were prepared by sol-gel methods of $\mathrm{SiO}_{2}$ and $\mathrm{SiO}_{2}-\mathrm{TiO}_{2}$ as a xerogel followed by impregnating $\mathrm{Nl}_{2} \mathrm{O}_{3}$ powder with the nickel nitrate precursor. The crystalline structure and catalytic properties for the catalysts were investigated by use of BET surface area, X-ray diffraction (XRD), Xray photoelectron spectroscopy (XPS) and temperature programmed reduction (TPR) techniques. These results show that nickel oxide is transformed to $\mathrm{Ni}_{\mathrm{N}} \mathrm{O}_{2} \mathrm{O}_{4}$ spinel structure at the calcination temperature of $400{ }^{\circ} \mathrm{C}$ in response to the steps with atter- and co-impregnation of $\mathrm{Nl}_{2} \mathrm{O}_{3}$ powder in sol-gel process. The $\mathrm{NiNl}_{2} \mathrm{O}_{4}$ could suppress the oxidation reaction of acetaldehyde by catalysts. The $\mathrm{NiO}$ is better dispersed on $\mathrm{SiO}_{2}-\mathrm{TiO}_{2} / \mathrm{Nl}_{2} \mathrm{O}_{3}$ support than $\mathrm{SiO}_{2} / \mathrm{Il}_{2} \mathrm{O}_{3}$ and $\mathrm{SiO}_{2}-\mathrm{TiO}_{2}-\mathrm{N}_{2} \mathrm{O}_{3}$ supports. From the testing results of catalytic activities for oxidation of acetaldehyde, Catalysts showed a big difference in conversion efficiencies with the way of the preparation of catalysts and the loading weight of nickel. The catalyst of $8 \mathrm{wt} \% \mathrm{Ni} / \mathrm{TiO}_{2}-\mathrm{SiO}_{2} / \mathrm{Nl}_{2} \mathrm{O}_{3}$ showed the best conversion efficiency on acetaldehyde oxidation with $100 \%$ conversion efficiency at $350^{\circ} \mathrm{C}$.
\end{abstract}

Key Words : Nickel (Ni), Oxidation catalyst, Sol-gel, $\mathrm{TiO}_{2}-\mathrm{SiO}_{2}$ xerogel, Acetaldehyde

\section{Introduction}

Catalytic converter offers an effective and economic alternative for purifying harmful gas exhausted by vehicles using petroleum as a main fuel.

The honeycomb ceramic support of catalytic converter assembly is coated with material of high surface area which acts as a host for the noble metal catalysts and additives. Besides the high surface area, other desirable washcoat properties are thermal, chemical, mechanical stability and appropriate pore size distribution. A material combining these properties and thus most widely used in this kind of application is $\gamma$-alumina.' The washcoat phase usually contains some quantities of other phases which have a particular function. For example, ceria and lanthania are frequently added to $y$-alumina in order to increase oxygen storage capacity and thermal stability, respectively. ${ }^{2-4}$

Recently, Tightening emission standards for automobile give an impulse to improve the natures of properties and to adopt the new technologies in catalytic converter. In case of washcoat, a performance is limited due to the uncontrolled porosity, the deactivation by coke formation and plugging in the micropore which hinders the diffusion of reactants and products. Thus oxide material supports with a narrow pore size distribution, uniform pore structure, and high pore volume are required for practical application.

Solid catalysts with high specific surface area, high homogeneity, and controlled redox properties are important in

"Present address: School of Mechanical Systems Engineering. Chonnam National University, Gwangiu 500-757, Korea catalytic converters. Chemical and physical properties of solid catalysts depend mainly on the procedures and conditions of preparation. There are several methods to prepare oxide mixture, which are conventional solid-state mixing, coprecipitation, and sol-gel process..$^{5}$

Binary solids of silica and titania are of great importance as glasses with low thermal expansion coefficient, catalyst supports, and catalysts. Preparation procedure of atomically mixed titania-silica as a mesoporous support has gained marked commercial and academic interest due to its potential as oxidation catalysts. A versatile method for achieving intimate mixing is the solution-sol-gel (SSG) technique, which represents a highly controllable preparation route to prepare active materials with high specific surface areas and homogeneity as well as tailored properties. This route provides a means for uniformly distributing different constituents at the atomic scale and forming materials with high specific areas. ${ }^{6}$

The sol-gel process involves two major reactions: hydrolysis (Eqs. (1a) and (1b)) and condensation (Eqs. 2(a) and (2b)).

Hydrolysis

$$
\begin{aligned}
\mathrm{M}(\mathrm{OR})_{\mathrm{z}}+\mathrm{xH}_{2} \mathrm{O} & \stackrel{\text { partially hydrolyzed }}{\longrightarrow}(\mathrm{HO})_{\mathrm{x}}-\mathrm{M}(\mathrm{OR})_{\mathrm{z}-\mathrm{x}}(1 \mathrm{a}) \\
& +\mathrm{xROH} ; \mathrm{o}<\mathrm{x}<\mathrm{z}
\end{aligned}
$$

Condensation

$$
\begin{aligned}
&(\mathrm{RO})_{z-1} \mathrm{M}-\mathrm{OH}+\mathrm{HO}-\mathrm{M}(\mathrm{OR})_{z-1} \\
& \rightarrow(\mathrm{RO})_{z-1} \mathrm{M}-\mathrm{OM}(\mathrm{OR})_{z-1}+\mathrm{H}_{2} \mathrm{O}
\end{aligned}
$$




$$
\begin{aligned}
(\mathrm{RO})_{z-1} \mathrm{M}-\mathrm{OR}+\mathrm{HO}-\mathrm{M}(\mathrm{OR})_{z-1} & \rightarrow(\mathrm{RO})_{z-1} \mathrm{M}-\mathrm{OM}(\mathrm{OR})_{z-1}+\mathrm{ROH}
\end{aligned}
$$

where $\mathrm{R}$ is typically an alkyl group, $\mathrm{M}$ the required metallic cations, and $\mathrm{z}$ the valance of cations. The above reactions can be controlled by adjusting the process parameters such as molar ratios of $\mathrm{H}_{2} \mathrm{O} / \mathrm{M}(\mathrm{OR}) \mathrm{x}, \mathrm{pH}$, reaction temperatures, acid, basic catalysts used, and the form and composition of raw materials. In preparing homogeneous multicomponent gels, comparable rates of hydrolysis and condensation are required during reaction.

With high thermal stability, superior adsorption capability with active components and good redox properties, mixed $\mathrm{TiO}_{2}-\mathrm{SiO}_{2}$ systems have attracted considerable attention as advanced materials to supersede single-oxide systems for catalytic supports.

In this study, catalytic activity of acetaldehyde among VOCs is estimated to confirm the oxidation catalyst supported on gel-derived $\mathrm{TiO}_{2}-\mathrm{SiO}_{2}$ support which plays a decisive role of a host for transition metals. Methodologies are also considered in synthesis to prepare the oxidation catalyst impregnated with gel-derived $\mathrm{TiO}_{2}-\mathrm{SiO}_{2}$ support. $\mathrm{TiO}_{2}-\mathrm{SiO}_{2}$ support plays a decisive role of a host for transition metal catalyst. Thus the catalytic activity is estimated in accordance with the prepared catalysts by variable methodologies in which the stages of impregnating with transition metal through sol-gel route deriving from the starting material, titanium chloride ( $\mathrm{TiCl}_{4}$ ) and tetraethyl orthosilicate (TEOS). Ni based metal catalyst as an oxidation catalyst is used, and acetaldehyde among VOCs is used as a target material to test catalytic activity.

The effects of different $\mathrm{Ni}$ impregnation stage during the preparation of catalyst derived $\mathrm{TiO}_{2}-\mathrm{SiO}_{2}$ xerogel were studied using BET experiments, X-ray diffraction analysis, $\mathrm{X}$-ray photoelectron spectroscopy, scanning electron microscopy(SEM) and catalytic activity test.

\section{Experimental}

Catalyst preparation. Four kinds of Ni-based catalysts were prepared by different methods, where variables were introduced in the stage of $\mathrm{Ni}$ impregnation during synthesis of catalysts derived xerogel.

Figure 1 shows the experimental procedure used to prepare $\mathrm{TiO}_{2}-\mathrm{SiO}_{2}$ particles. A typical synthesis, adopted from one step hydrolysis, of $\mathrm{SiO}_{2}$ or $\mathrm{TiO}_{2}-\mathrm{SiO}_{2}$ composite xerogel samples was proceded with the following precursors: tetraethyloxysilane (TEOS), $\mathrm{TiCl}_{4}$, acetic acid. distilled water. Ethanol was used as a mutual solvent, and the hydrolysant consisted of doubly distilled water and acetic acid.

The experimental parameters of molar ratios of $\mathrm{H}_{2} \mathrm{O}$ / alkoxides or $\mathrm{H}_{2} \mathrm{O} /$ chlorides and $\mathrm{pH}$ of the starting solutions on the resultant particles were considered from previous studies. The molar value of $0.051 \mathrm{TEOS}$ to $\mathrm{TiCl}_{4}$ resulted in $60 \mathrm{wt} \% \mathrm{SiO}_{2}$ and $40 \mathrm{wt} \% \mathrm{TiO}_{2}$, and also the molar ratios corresponding to the solution of starting material was TEOS: $\mathrm{TiCl}_{4}: \mathrm{EtOH}: \mathrm{H}_{2} \mathrm{O}: \mathrm{CH}_{3} \mathrm{COOH}=\mathrm{x}: \mathrm{y}: 7(\mathrm{x}+\mathrm{y}): 10(\mathrm{x}+\mathrm{y}): 2(\mathrm{x}+\mathrm{y})$.

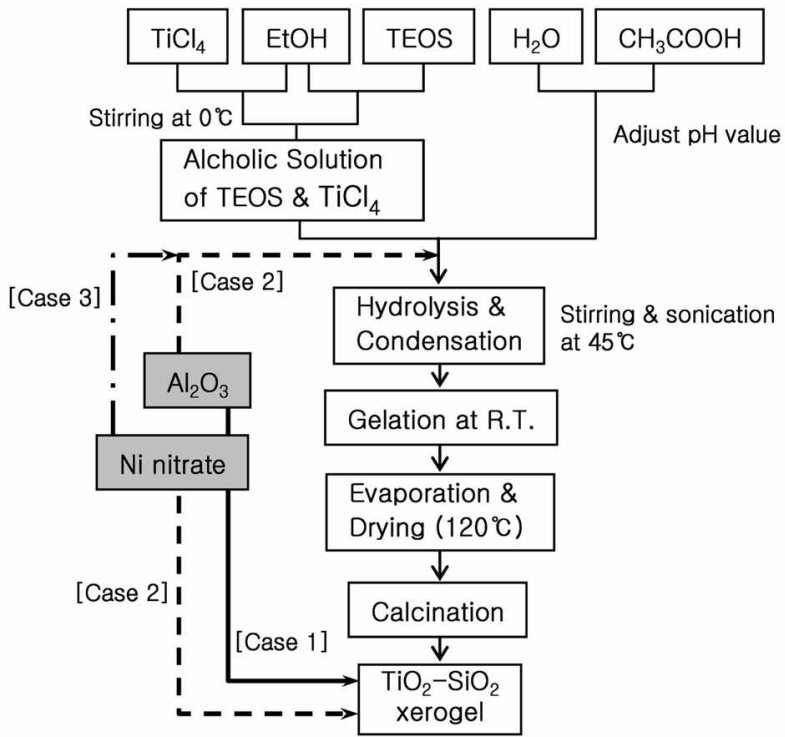

Figure 1. Experimental procedures for preparing the $\mathrm{TiO}_{2}-\mathrm{SiO}_{2}$ xerogel and cases of catalysts classificd.

Firstly, EtOH, TEOS, $\mathrm{H}_{2} \mathrm{O}$ and $\mathrm{CH}_{3} \mathrm{CHOOH}$ were mixed by stirring and then $\mathrm{TiCl}_{4}$ alcoholic solution was added at 0 ${ }^{\circ} \mathrm{C}$ under vigorous stirring. The $\mathrm{pH}$ value of metal alcoholic solution was maintained as 2 . The resulting sol was stirred for 20 minutes and sonicated for 270 minutes in ultrasonication bath followed by gelling at room temperature for $24 \mathrm{~h}$. After that it was treated with ammonia to change $\mathrm{pH}$ up to 9 , and then gel was neutralized by distilled water. Finally, gel was evaporated by rotary evaporator followed by drying for $12 \mathrm{~h}$ at $120^{\circ} \mathrm{C}$ and calcining for $4 \mathrm{~h}$ at $400^{\circ} \mathrm{C}$.

To prepare the oxidation catalyst, support consists of $\mathrm{TiO}_{2}-$ $\mathrm{SiO}_{2}$ xerogel and $\gamma$-alumina is impregnated with Ni. Nickel (II) nitrate hexalhydrate was used as $\mathrm{Ni}$ starting material and commercial $\gamma$-alumina of 150 mesh was used. The samples were variable with the stage of $\mathrm{Ni}$ impregnation during synthesis of sol-gel or after xerogel powder:

Catalyst characterization. The BET method was used to analyze nitrogen adsorption-desorption data at $77 \mathrm{~K}$. Surface areas, pore volumes, and pore size distributions of tested samples were measured.

The XRD diagrams, which were used to determine chemical phases of the resultant samples, were recorded with $\mathrm{Cu}-\mathrm{K}_{\alpha}$ radiation over a $2 \theta$ range of $20-80^{\circ}$. The particles and crystallite morphologies of the obtained samples were observed from their SEM photomicrographs.

$\mathrm{X}$-ray photoelectron spectra (XPS, Physical Electronics Quantum 2000 Scanning ESCA Probe) were recorded on a Al $\mathrm{K}_{\alpha}(\lambda=1.5406)$ radiation for exciting photoelectrons. All binding energies were referenced to the adventitious $\mathrm{C}$ 1s line at $284.7 \mathrm{eV}$.

Temperature-programmed reduction (TPR) was canied out by $10 \% \mathrm{H}_{2} / \mathrm{Ar}$, at a flow rate of $25 \mathrm{~mL} / \mathrm{min}$, after $100 \mathrm{mg}$ of the sample was oxidized at $500^{\circ} \mathrm{C}$. A linear increase of temperature to $900^{\circ} \mathrm{C}$ at a rate of $15^{\circ} \mathrm{C} / \mathrm{min}$ was adopted. The consumption of $\mathrm{H}_{2}$ was measured with TCD. 
Table 1. Acronyıns and Physicochemical propertics of the samples

\begin{tabular}{|c|c|c|c|c|}
\hline Sample & $\begin{array}{l}\text { Composition (wt.\%) } \\
\mathrm{Ni}: \mathrm{TiO}_{2}: \mathrm{SiO}_{2}: \mathrm{Al}_{2} \mathrm{O}_{3}\end{array}$ & $\begin{array}{c}\text { BET surface area } \\
\left(\mathrm{m}^{2} / \mathrm{g}\right)\end{array}$ & $\begin{array}{l}\text { Pore volume } \\
\text { (cm/g) }\end{array}$ & $\begin{array}{l}\text { Pore diameter } \\
\text { (nim) }\end{array}$ \\
\hline $\mathrm{Al}_{2} \mathrm{O}_{3}$ & $0: 0: 0: 100$ & 131.66 & 0.27 & 6.39 \\
\hline $\mathrm{SiO}_{2}$ & $0: 0: 100: 0$ & 652.30 & 0.86 & 4.96 \\
\hline $\mathrm{TiO}_{2}-\mathrm{SiO}_{2}$ & $0: 40: 60: 0$ & 411.83 & 0.82 & 7.40 \\
\hline $\mathrm{TiO}_{2}-\mathrm{SiO}_{2}-\mathrm{Al}_{2} \mathrm{O}_{3}$ & $0: 20: 30: 50$ & 334.24 & 0.41 & 4.49 \\
\hline $\mathrm{SiO}_{2}-\mathrm{Al}_{2} \mathrm{O}_{3}-\mathrm{Ni}$ & $8: 0: 5: 42$ & 319.29 & 0.50 & 5.55 \\
\hline${ }^{*} \mathrm{TiO}_{2}-\mathrm{SiO}_{2}-\mathrm{Al}_{2} \mathrm{O}_{3}-\mathrm{Ni}$ & $8: 20: 30: 42$ & 231.75 & 0.48 & 7.47 \\
\hline${ }^{*+} \mathrm{TiO}_{2}-\mathrm{SiO}_{2}-\mathrm{Al}_{2} \mathrm{O}_{3}-\mathrm{Ni}$ & $8: 20: 30: 42$ & 242.26 & 0.33 & 4.99 \\
\hline${ }^{+*+*} \mathrm{TiO}_{2}-\mathrm{SiO}_{2}-\mathrm{Al}_{2} \mathrm{O}_{3}-\mathrm{Ni}$ & $8: 20: 30: 42$ & 279.96 & 0.35 & 4.51 \\
\hline
\end{tabular}

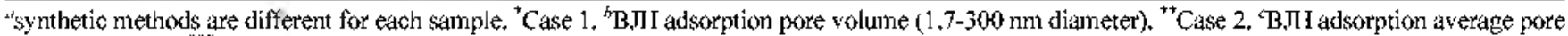
diameter (4V/A). " Case 3

Catalytic reaction. The catalytic activity test was conducted in a fixed-bed reactor of a quartz tube $(6 \mathrm{~mm}, \mathrm{i} . \mathrm{d}$.) under atmospheric pressure. One hundred milligrams of catalyst was loaded for each test. The catalysts were flushed under $\mathrm{N}_{2}$ flow at $500^{\circ} \mathrm{C}$ for $2 \mathrm{~h}$ before reaction.

The reaction gases contained $500 \mathrm{ppm}$ acetaldehyde and $10 \%$ air in total gas flow of $100 \mathrm{~mL} / \mathrm{min}$. The reactant and product composition were analyzed on-line with a HP-6890 gas chromatograph equipped with a flame ionization detector (FID).

\section{Results and Discussion}

Characteristics of catalysts. The specific BET surface area of the oxidation catalysts was dependent on the supports including $\mathrm{TiO}_{2}-\mathrm{SiO}_{2}$ xerogel and commercial $\gamma$ alumina as listed in Table 1 . Surface area of $\mathrm{SiO}_{2}$ xerogel decreased with forming into composite powder with $\mathrm{TiO}_{2}$ and $\gamma$-alumina. However, the specific surface area showed a wide difference between xerogel powder and commercial $\gamma$ alumina. This is continued to the sample impregnated with transition metal Ni.

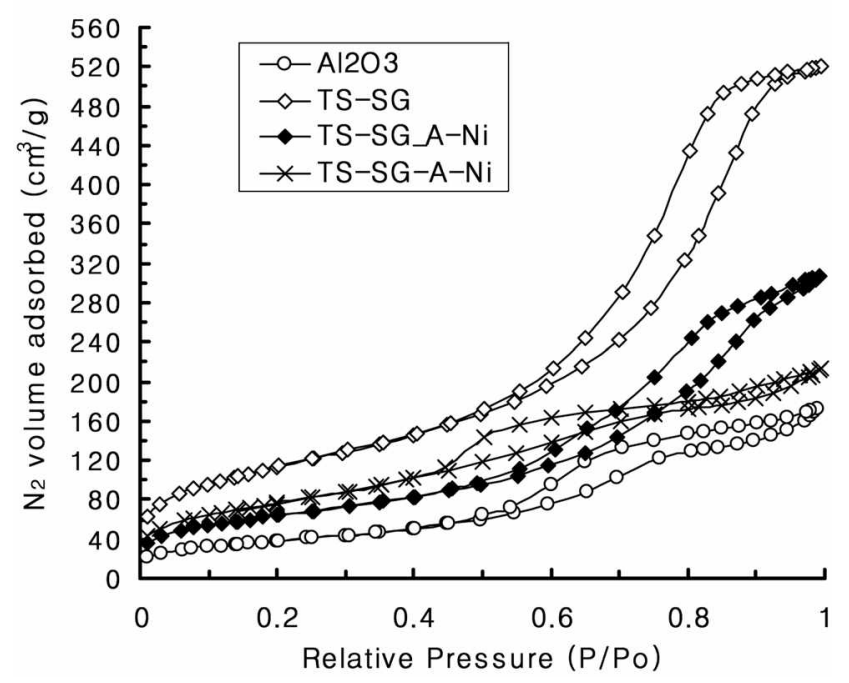

Figure 2. $\mathrm{N}_{2}$ adsorption-desorption isotheruns of mesoporous powders.
The pore properties especially specific BET surface area $\left(\mathrm{m}^{2} / \mathrm{g}\right)$ were affected by supports. Figure 2 shows the typical patterns of $\mathrm{N}_{2}$ adsorption-desorption isotherm curves. The isothermal adsorption curves for gel-derived $\mathrm{TiO}_{2}-\mathrm{SiO}_{2}$ xerogel composites was between type II and III of the IUPAC classifications, indicating that the obtained $\mathrm{TiO}_{2}-$ $\mathrm{SiO}_{2}$ xerogel composites contained both mesopores and macropores. Pore size distributions are presented in Figure 3 corresponding to $\mathrm{BJH}$ pore sizes obtained from the desorption isothems. Mesoporous property of the samples impregnated with $\mathrm{Ni}$ on mixed powder of $\mathrm{TiO}_{2}-\mathrm{SiO}_{2}$ xerogel and $\mathrm{Al}_{2} \mathrm{O}_{3}, \mathrm{SiO}_{2} / \mathrm{Al}_{2} \mathrm{O}_{3}-\mathrm{Ni}$ and

$\mathrm{TiO}_{2}-\mathrm{SiO}_{2} / \mathrm{Al}_{2} \mathrm{O}_{3}-\mathrm{Ni}$, are well developed with large pore volume (from Table 1, BJH adsorption pore volume, 1.7-300 $\mathrm{nm}$ diameter) than that of the samples impregnated simultaneously with $\mathrm{Ni}$ and/or $\mathrm{Al}_{2} \mathrm{O}_{3}$ during sol-gel process for resultants $\mathrm{TiO}_{2}-\mathrm{SiO}_{2}$ xerogel powder, $\mathrm{TiO}_{2}-\mathrm{SiO}_{2}-\mathrm{Al}_{2} \mathrm{O}_{3} \mathrm{Ni}$ and $\mathrm{TiO}_{2}-\mathrm{SiO}_{2}-\mathrm{Al}_{2} \mathrm{O}_{3}-\mathrm{Ni}$.

Figure 4 shows the SEM photomicrographs of the gelderived $\mathrm{TiO}_{2}-\mathrm{SiO}_{2}$ xerogel composites. By examining these SEM photomicrographs, it is clear that all of the samples were composed of secondary particles with submicron size which were formed from the agglomeration of nano scaled

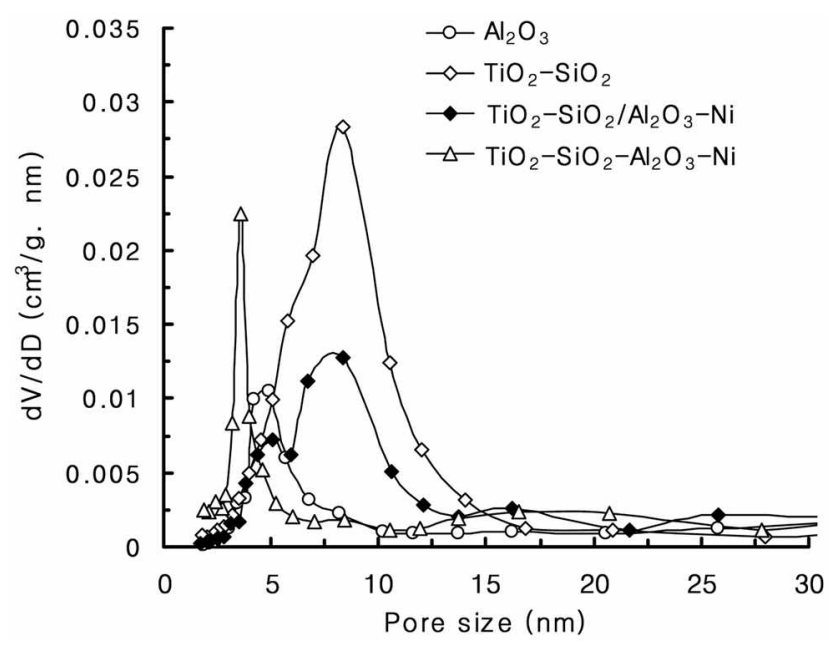

Figure 3. Pore size distribution of the gel-derived $\mathrm{TiO}_{2}-\mathrm{SiO}_{2}$ xerogel composites. 


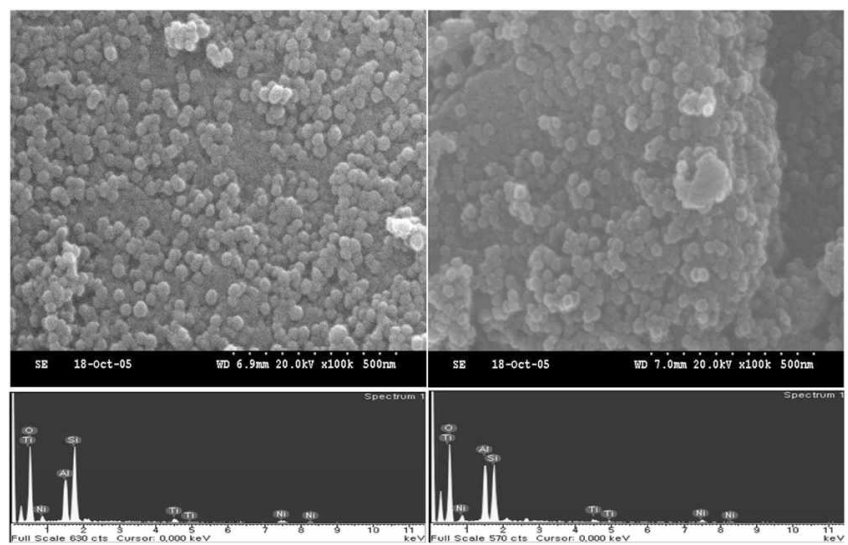

Figure 4. SEM photomicrographs of the gel derived $\mathrm{TiO}_{2}-\mathrm{SiO}_{2}$ xerogel composites, $\mathrm{TiO}_{2}-\mathrm{SiO}_{2} / \mathrm{Nl}_{2} \mathrm{O}_{3}-\mathrm{Ni}$ and $\mathrm{TiO}_{2}-\mathrm{SiO}_{2}-\mathrm{Nl}_{2} \mathrm{O}_{3}-\mathrm{Ni}$.

Table 2. Results of XPS measurement for the gel-derived $\mathrm{TiO}_{2}-$ $\mathrm{SiO}_{2}$ xerogel composites

\begin{tabular}{lccc}
\hline & $\mathrm{Xc}\left(\mathrm{NI}_{2 \mathrm{p}}\right)$ & Width & Area \\
\hline $\mathrm{SiO}_{2} / \mathrm{Al}_{2} \mathrm{O}_{3}-\mathrm{Ni}$ & 856.08 & 4.247 & 2738.3 \\
$\mathrm{TiO}_{2}-\mathrm{SiO}_{2} / \mathrm{Al}_{2} \mathrm{O}_{3}-\mathrm{Ni}$ & 855.57 & 5.30 & 2187.3 \\
$\mathrm{TiO}_{2}-\mathrm{SiO}_{2} / \mathrm{Al}_{2} \mathrm{O}_{3} / \mathrm{Ni}$ & 855.51 & 5.24 & 1720.8 \\
$\mathrm{TiO}_{2}-\mathrm{SiO}_{2} / \mathrm{Al}_{2} \mathrm{O}_{3}-\mathrm{Ni}$ & 856.45 & 4.23 & 1544.0 \\
\hline
\end{tabular}
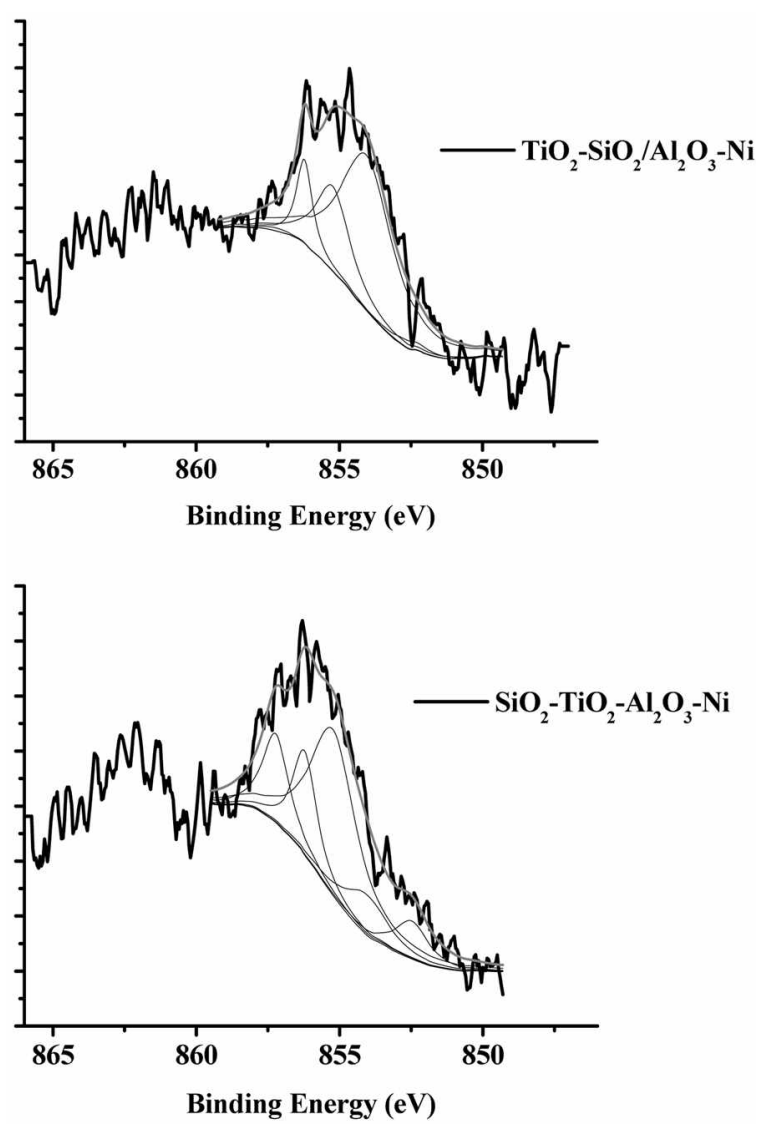

Figure 5. XPS spectra of the gel-derived $\mathrm{TiO}_{2}-\mathrm{SiO}_{2}$ xerogel composites.

primary particles. The size distribution of secondary particles of $\mathrm{TiO}_{2}-\mathrm{SiO}_{2} / \mathrm{Al}_{2} \mathrm{O}_{3}-\mathrm{Ni}$ was more uniform than that of

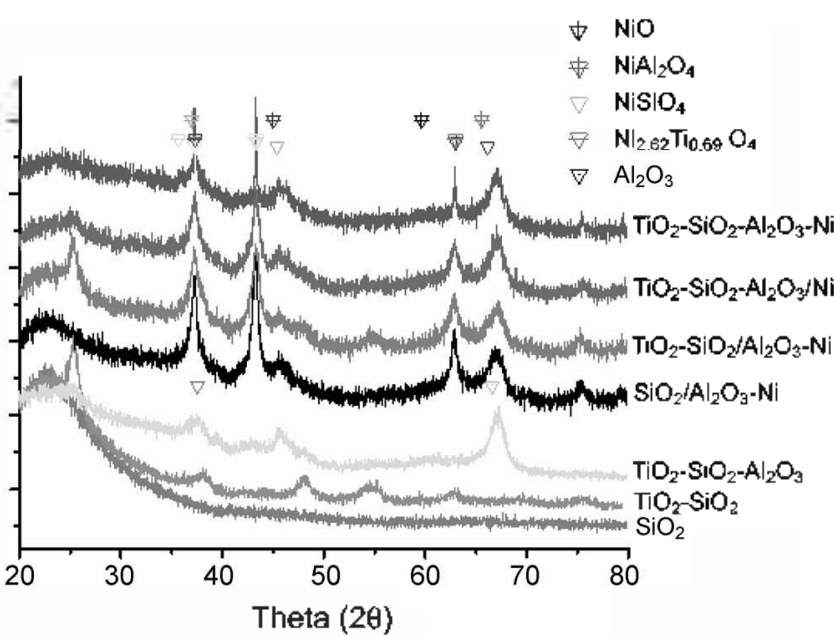

Figure 6. XRD spectra of the gel-derived $\mathrm{TiO}_{2}-\mathrm{SiO}_{2}$ xerogel composites.

$\mathrm{TiO}_{2}-\mathrm{SiO}_{2}-\mathrm{Al}_{2} \mathrm{O}_{3}-\mathrm{Ni}$ and the agglomeration tends to spheroidize. These suggests that the different methods to prepare $\mathrm{TiO}_{2}-\mathrm{SiO}_{2}$ composites affect the gelation procedure via micelle stage by $\gamma$-alumina powder, which squeezes itself in jonic metals during condensation procedure after hydrolysis.

The results of XPS analysis of the gel-derived $\mathrm{TiO}_{2}-\mathrm{SiO}_{2}$ xerogel composites, $\mathrm{TiO}_{2}-\mathrm{SiO}_{2} / \mathrm{Al}_{2} \mathrm{O}_{3}-\mathrm{Ni}$ and $\mathrm{TiO}_{2}-\mathrm{SiO}_{2}-$ $\mathrm{Al}_{2} \mathrm{O}_{3}-\mathrm{Ni}$, are shown in Figure 5 and are also listed in Table 2 . The binding energy of $\mathrm{Ni} 2 \mathrm{p}_{3: 2}$ measured for Ni-based catalysts supported by gel derived $\mathrm{TiO}_{2}-\mathrm{SiO}_{2}$ xerogel is well defined at $852-857 \mathrm{eV}$. In this binding energy, nickel is mainly in oxidation state of $\mathrm{Ni}^{+}-\mathrm{Ni}^{+3}$, and few metallic states. The binding energy of $\mathrm{Ni} 2 \mathrm{p}_{3: 2}$ measured for $\mathrm{TiO}_{2}-$ $\mathrm{SiO}_{2} / \mathrm{Al}_{2} \mathrm{O}_{3}$, which $\mathrm{Ni}(855.57 \mathrm{eV})$ is slightly lower than the value of $\mathrm{TiO}_{2}-\mathrm{SiO}_{2}-\mathrm{Al}_{2} \mathrm{O}_{3}-\mathrm{Ni}(856.45 \mathrm{eV})$. This result suggested that the binding energy of $\mathrm{Ni} 2 \mathrm{p}_{3: 2}$ is lower for the highly dispersed $\mathrm{Ni}$ which corresponds to the coverage of the support below monolayer than for bulk.

The width and area of binding energy for $\mathrm{Ni} 2 \mathrm{p}_{3 / 2}$ from $\mathrm{TiO}_{2}-\mathrm{SiO}_{2} / \mathrm{Al}_{2} \mathrm{O}_{3}-\mathrm{Ni}$ are bigger than those of $\mathrm{TiO}_{2}-\mathrm{SiO}_{2}-$ $\mathrm{Al}_{2} \mathrm{O}_{3}-\mathrm{Ni}$, which represents the oxidation potential of Ni. By the process of peak deconvolution, higher binding energy of $\mathrm{Ni} 2 \mathrm{p}_{32}$ in $\mathrm{TiO}_{2}-\mathrm{SiO}_{2}-\mathrm{Al}_{2} \mathrm{O}_{3}-\mathrm{Ni}$ is observed than that of $\mathrm{TiO}_{2}-\mathrm{SiO}_{2} / \mathrm{Al}_{2} \mathrm{O}_{3}-\mathrm{Ni}$. This result is considered to occur due to the enhancement of the interaction between oxidized $\mathrm{Ni}$ and supports, which is related to form the spinel structure.

From the results of XRD in Figure 6, gel-derived xerogel composites are identified with $\mathrm{Al}_{2} \mathrm{O}_{3}$ as $\gamma$-alumina and $\mathrm{TiO}_{2}$ as anatase, respectively. Nickel oxides are well defined on gel-derived $\mathrm{TiO}_{2}-\mathrm{SiO}_{2}$ xerogel composites and also the identification of nickel oxide turns out to be nickel composite such as $\mathrm{NiAl}_{2} \mathrm{O}_{4}$ and $\mathrm{Ni}_{2} \mathrm{TiO}_{4}$ as a spinel structure.

$\mathrm{TiO}_{2}-\mathrm{SiO}_{2}-\mathrm{Al}_{2} \mathrm{O}_{3}-\mathrm{Ni}$ is distinct from crystalline phase of nickel cation. The interaction between the nickel and supports is stronger in $\mathrm{TiO}_{2}-\mathrm{SiO}_{2}-\mathrm{Al}_{2} \mathrm{O}_{3}-\mathrm{Ni}$ than others. These interactions between nickel oxides and supports produce nickel composite such as nickel silicate $\left(\mathrm{Ni}_{2} \mathrm{SiO}_{4}\right)$, nickel titanium oxide $\left(\mathrm{Ni}_{x} \mathrm{Ti}_{y} \mathrm{O}_{4}\right)$ and nickel aluminate $\left(\mathrm{NiAl}_{2} \mathrm{O}_{4}\right)$. 


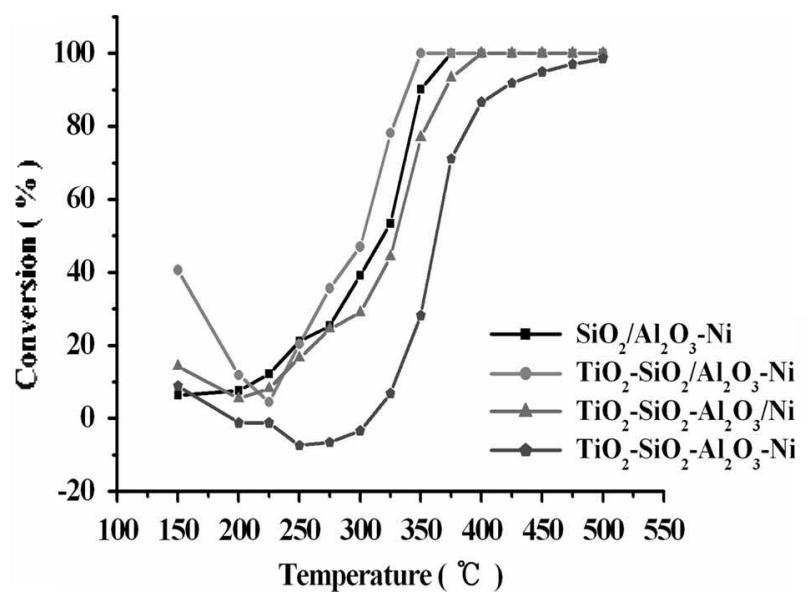

Figure 7. Catalytic activity of Ni-based catalyst supported on gelderived $\mathrm{TiO}_{2}-\mathrm{SiO}_{2}$ xerogel composites for oxidation of acctaldehyde.

Catalytic activity. The catalytic activities of acetaldehyde oxidation over Ni-based catalysts are shown in Figure 7. It is clear from Figure 7 that the light-off temperature of $\mathrm{TiO}_{2}$ $\mathrm{SiO}_{2}-\mathrm{Al}_{2} \mathrm{O}_{3}-\mathrm{Ni}$ catalyst is obviously lower than that of $\mathrm{TiO}_{2}-$ $\mathrm{SiO}_{2} / \mathrm{Al}_{2} \mathrm{O}_{3}-\mathrm{Ni}$ catalyst. The catalytic activity is initiated around $220^{\circ} \mathrm{C}$ with the exception of $\mathrm{TiO}_{2}-\mathrm{SiO}_{2}-\mathrm{Al}_{2} \mathrm{O}_{3}-\mathrm{Ni}$ catalyst. The light-off temperature for $50 \% \mathrm{CH}_{3} \mathrm{COOH}$ conversion (LOT:0) of $\mathrm{TiO}_{2}-\mathrm{SiO}_{2}-\mathrm{Al}_{2} \mathrm{O}_{3}-\mathrm{Ni}$ catalyst was found to be around $360^{\circ} \mathrm{C}$. The $\mathrm{LOT}_{50}$ of $\mathrm{TiO}_{2}-\mathrm{SiO}_{2} / \mathrm{Al}_{2} \mathrm{O}_{3}-$ $\mathrm{Ni}$ catalyst was observed to be $300^{\circ} \mathrm{C}$ and that of ful] conversion of this catalyst was found to be $350^{\circ} \mathrm{C}$. From the case of $\mathrm{TiO}_{2}-\mathrm{SiO}_{2}-\mathrm{Al}_{2} \mathrm{O}_{3}-\mathrm{Ni}$, it was found that $\mathrm{Ni}$ oxides were attracted to the supports with strong interaction which result in decrease in catalytic activity. Consequently, Oxides in lattice of spinel structure composites such as $\mathrm{NiAl}_{2} \mathrm{O}_{4}$ and $\mathrm{Ni}_{2} \mathrm{TiO}_{4}$ decrease the oxidation potential of transition metal.

\section{Conclusion}

The following conclusions can be drawn from the results of present study:

1. Surface characteristics of xerogel supports are control- led by nano-scale with $411 \mathrm{~m}^{2} / \mathrm{g}$ of BET surface area and pore diameter of $7.4 \mathrm{~nm}$ on $\mathrm{TiO}_{2}-\mathrm{SiO}_{2}$ xerogel.

2. Based on the results of XPS, Nickel is defined as $\mathrm{Ni} 2 \mathrm{p}_{3 / 2}$ at $852-857 \mathrm{eV}$ binding energy. $\mathrm{Ni} 2 \mathrm{p}_{3 / 2}$ of $\mathrm{TiO}_{2}-\mathrm{SiO}_{2}-\mathrm{Al}_{2} \mathrm{O}_{3}-$ $\mathrm{Ni}$ is distributed at higher binding energy than other species.

3. From the results of XRD, Nickel oxides are identified with the nickel composite such as $\mathrm{NiAl}_{2} \mathrm{O}_{3}$ and $\mathrm{Ni}_{2} \mathrm{TiO}_{4}$ resulted from the interaction between the nickel and supports.

4. $\mathrm{TiO}_{2}-\mathrm{SiO}_{2} / \mathrm{Al}_{2} \mathrm{O}_{3}-\mathrm{Ni}$ with $80 \%$ of conversion at $320^{\circ} \mathrm{C}$ is superior to others. $\mathrm{TiO}_{2}-\mathrm{SiO}_{2}-\mathrm{Al}_{2} \mathrm{O}_{3}-\mathrm{Ni}$ shows the poorest performance. It is supposed that the nickel composites such as $\mathrm{NiAl}_{2} \mathrm{O}_{3}$ and $\mathrm{Ni}_{2} \mathrm{TiO}_{4}$ suppress the oxidation reaction on catalyst.

Acknowledgement. This research was supported by the Korea Industrial Technology Foundation via the program for cultivating graduate students in a regional strategic industry. This work was also supported by grant No. RT 104-03-02 from the Regional Technology Innovation Program of the Ministry of Commerce, Industry and Energy (MOCIE).

\section{References}

I. Goodby, K. P.; Downing, J. C. Ahmina Chemicals: Science and Technology Handbook; The American Ceramic Society Inc.; Westerville, OH, USA, 1990.

2. Oh, S. H. J. Catalysis 1990, $124,477$.

3. Diwell, A. F.; Rajaram, R. R.; Shaw, H. A.; Truex, T. J. Catalysis and Automotive Pollution Control II, Vol. 71, Studies in Surface Science and Catahsis; Elsevier Science Publishers, B.V: Amsterdam, 1999.

4. Tijburg. I. I. M.; Geus, J. W; Zandbergen, H. W. J. Mat. Sci. 1991 , 26,6479 .

5. Makolo, T.; Fujio, M.; Shu-ichi, N.; Tsuneji, S.; Kazuyuki, M.; Arto, A.; Veikko, K. J. Molec. Catal, 1994, 91, 277.

6. Yu, H. F.; Wang S. M. J. of Non-Cry Solids 2000, 261, 260 ,

7. Dutoit, D. C. M., Schneider, M.; Baiker, A. J. of Catahtsis 1995. 153,165 .

8. Hussain, S. T.; Nadeem, M. A.; Mazhar, M.; Larachi, F. Bull Korean Chem. Soc. 2007, 28, 529.

9. Choi, H. J.; Kim, J. S.; Kang, M. S. Bull. Korean Chem. Soc. $2007,28,581$. 